\title{
Rapid changes in tree composition and biodiversity: consequences of dams on dry seasonal forests
}

Vagner S Vale ${ }^{1 *}$, I Schiavini ${ }^{1}$, J A Prado-júnior ${ }^{1}$, Ana P Oliveira and André E Gusson ${ }^{2}$

\begin{abstract}
Background: Plants in a seasonal environment that become close to the artificial lake after dams construction may have enhanced growth or die due to the new conditions. Changes in mortality or growth rates lead to changes in community diversity, and we do not know if the community functions will change; our main hypothesis was that a few years after impoundment, species richness and diversity will increase because the increased supply of water would favor the establishment of water-associated species. Therefore, we evaluated the consequences of proximity of three dry seasonal forests to the water table after damming, with a dynamic evaluation of the species studied to understand changes in diversity in these areas. We sampled 60 plots of $20 \times 10 \mathrm{~m}$ in each forest and measured all trees with a diameter equal to or greater than $4.77 \mathrm{~cm}$ before damming and 2 and 4 years after damming. We calculated dynamic rates and compared species changes during these periods. We also compared diversity and richness using Shannon index and rarefaction curves.
\end{abstract}

Results: Many species had high dynamic rates and many trees of specialists of dry forests died; conversely, others had high growth rates. Some typical species of riparian forests were found only after damming, also enhancing forest richness in deciduous forests. In general, the deciduous forest communities seemed to change to a typical riparian forest, but many seasonal specialist species still had high recruitment and growth rate, maintaining the seasonal traits, such as dispersion by wind and deciduousness in the forests, where an entire transformation did not occur.

Conclusions: We conclude that even with the increment in basal area and recruitment of many new species, the impacts of damming and consequent changes will never lead to the same functions as in a riparian forest.

Keywords: Dynamic; Ecological changes; Impoundment; Richness; Turnover

\section{Background}

Dams have historically facilitated human life, initially in farming, transport, and domestic services, and are currently mainly built for energy generation (Baxter 1977). At least 45,000 dams over $15 \mathrm{~m}$ high obstruct $60 \%$ of fresh water that flows to the oceans (Nilsson et al. 2005). Dam construction increased because hydroelectric power was considered a clean and inexpensive alternative for energy production (Kaygusuz 2004), responsible for $16 \%$ of worldwide electricity generation in 2005 (Evans et al. 2009). Despite the spread of this

\footnotetext{
* Correspondence: vsvale@hotmail.com

'Universidade Estadual de Goiás (State University of Goiás) - Campus Ipameri, CEP 75780-000, Ipameri, Goiás, Brasil

Full list of author information is available at the end of the article
}

"clean and inexpensive" idea, several problems are actually known, such as entire watershed modification (Nilsson and Berggren 2000), sediment retention (Manyari and Carvalho 2007; Vorosmarty et al. 2003), biochemical alterations (Humborg et al. 1997), and emission of greenhouse gases (Fearnside 2002; St Louis et al. 2000).

Water-dwelling organisms (fish, amphibians, plankton, benthos, and macrophytes) are directly affected, causing drastic changes in food webs (Brandao and Araujo 2008; Moura Júnior et al. 2011). The artificial lake created also interferes with terrestrial organisms. Wildlife can move to habits outside the flooded area, but sessile organisms such as plants are drowned (Fearnside 2002; White 2007). Plant decomposition releases organic matter and 
depletes water oxygen (Barth et al. 2003; St Louis et al. 2000), also releasing carbon dioxide $\left(\mathrm{CO}_{2}\right)$ and methane $\left(\mathrm{CH}_{4}\right)$ to the atmosphere (St Louis et al. 2000). However, organisms living in the direct flood influence area are not the only ones affected. The vegetation distant from any water source before damming is afterwards near the margin of the lake created by the dam, and long-term consequences are difficult to prevent because this new "riparian vegetation" is completely different from an original riparian environment in species and characteristics.

Riparian vegetation includes species adapted to water saturation and species adapted to low water patches, and thus commonly shows high diversity (Naiman and Decamps 1997). These environments are associated with many ecological services, such as connecting aquatic and terrestrial habitats (Dynesius and Nilsson 1994), providing resources for fish (Jansson et al. 2005) and other dispersers such as birds and mammals (Gundersen et al. 2010; Naiman and Decamps 1997), and promoting refuge for these animals (Palmer and Bennett 2006), thus playing a key role in diversity maintenance.

However, vegetation that becomes near the new margins created by dams are located on hillsides (Truffer et al. 2003; Vale et al. 2013), without species associated with high water saturation, in other words, with different species composition (Acker et al. 2003) and with different traits compared to typical riparian vegetation. Terrain with steep slopes facilitates water flow and reduces water infiltration into the soil (Sidle et al. 2006). Moreover, hills have rocky soil that makes water retention even more difficult. Due to these conditions, species of these environments show adaptation to reduce water loss due to water-stressed conditions, such as loss of leaves during dry season and fruits and seeds with low water content (Murphy and Lugo 1986), and tend to have higher wood density to prevent drought-induced embolism (Choat et al. 2003). Thus, it is not only difficult to prevent the consequences of proximity to the water line on these drought-adapted species, but it is also uncertain if the "new riparian vegetation" will provide the ecological functions of a typical riparian vegetation.

Many dams have been built and will continue to be built, and therefore, understanding vegetation changes after damming is crucial for better conservation and future management actions. Thus, we monitored three seasonal forests that were subjected to the impact of a hydroelectric dam to answer the following questions: Which were the species best adapted to new conditions imposed by the dam? Which were negatively affected? Which new species were established? Were there any local extinctions? Finally, would the "new-riparian vegetation" maintain the ecological roles performed by typical riparian vegetation? Our hypothesis was that a few years after impoundment, species richness and diversity increase because the increased supply of water would favor the establishment of water-associated species. On the other hand, it would cause the mortality of many tree species commonly found in forests with a wellestablished dry season.

\section{Methods}

\section{Study area}

This study was conducted in three dry forests $\left(18^{\circ} 47^{\prime}\right.$ $40^{\prime \prime} \mathrm{S}, 48^{\circ} 08^{\prime} 57^{\prime \prime} \mathrm{W} ; 18^{\circ} 40^{\prime} 31^{\prime \prime} \mathrm{S}, 42^{\circ} 24^{\prime} 30^{\prime \prime} \mathrm{W}$; and $18^{\circ}$ $39^{\prime} 13^{\prime \prime}$ S, 48 $25^{\prime} 04$ W; Fig. 1) located in the Amador Aguiar Complex Dam (two dams located on the Araguari River, with reservoir depths of 52 and $55 \mathrm{~m}$ ). All areas had a sloped terrain, but the deciduous forest inclinations were much more pronounced compared to the semideciduous forest (in some plots, the inclination was over $30^{\circ}$ ). The first dam (Amador Aguiar Dam I, henceforth AD1) finished flooding in 2005 and has an elevation of $624 \mathrm{~m}$ (relative to sea level) and the second dam (Amador Aguiar Dam II, henceforth AD2) ended flooding in 2006 and has an elevation of $565 \mathrm{~m}$ (relative to sea level, more information in Vale et al. 2013).

Three dry seasonal forests (two deciduous and one semideciduous forest), which before damming were at least $200 \mathrm{~m}$ from any water source, now had the riverbank at its edge after damming since 2005 (AD1)/2006 (AD2). The dam water flow was constant, and thus, the water flow did not vary over seasons and over years. Earlier analyses made in three areas confirmed the damming effects of moisture increase in soil at least $15 \mathrm{~m}$ from the artificial lake margin created by the dam (Vale et al. 2013). This impact clearly affects the entire community (Vale et al. 2013), and the responses of tree species to river damming were analyzed here. The climate of the study area is Aw according to the Koppen-Geiger classification (Kottek et al. 2006) with a dry winter (April to September) and a rainy summer (October to March), with an average annual temperature of $22{ }^{\circ} \mathrm{C}$ and average rainfall of around $1595 \mathrm{~mm}$ (Santos and Assunção 2006).

\section{Plant sampling}

The first inventory (T0) was carried out in 2005 (AD1) and 2006 (AD2). In each forest, 60 permanent plots $20 \times$ $10 \mathrm{~m}$ were marked, totaling 1.2 ha by area (total of 3.6 ha sampled). A total of 10 plots (200 m wide) were established where the river reached the maximum flood level after damming, and the remaining plots were established perpendicular to the river margin. Thus, the samples were distributed every $10 \mathrm{~m}$ of perpendicular to the river $(0=10 \mathrm{~m}, 10=20 \mathrm{~m}, 20-30 \mathrm{~m}, 30-40 \mathrm{~m}, 40-50 \mathrm{~m}$, and $50-60 \mathrm{~m}$ of distance). All trees with a diameter at breast height $(\mathrm{DBH})$ of $4.77 \mathrm{~cm}$ were tagged with aluminum labels. The diameter of the stem was 


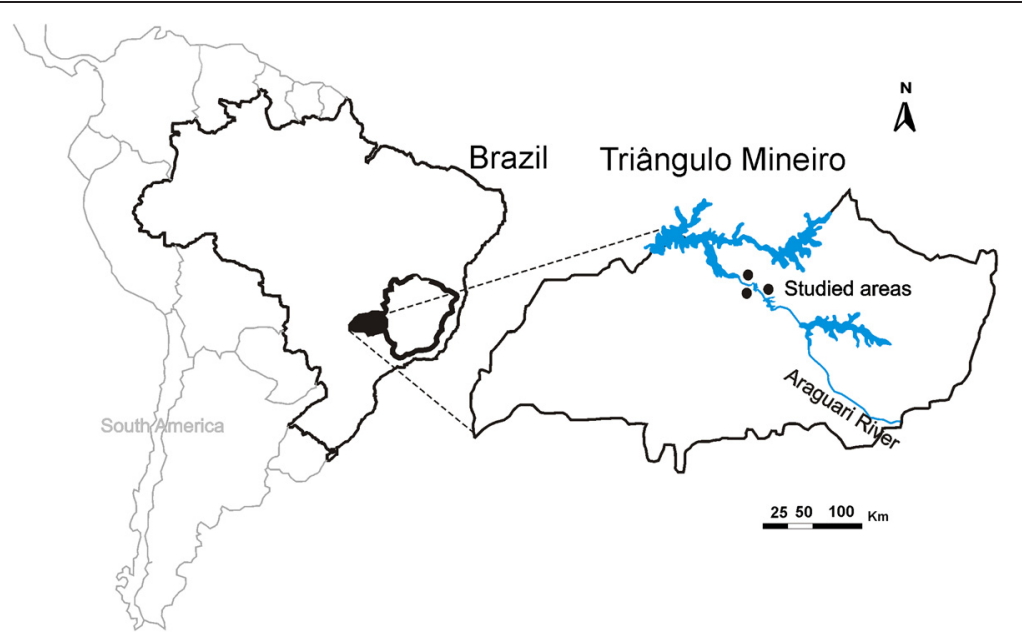

Fig. 1 Location of three dry forests that were affected by the Amador Aguiar Complex Dam, in Triângulo Mineiro, Southeastern Brazil. Before dam construction these forests were far from water sources and now are on the artificial lake margin

measured at $1.30 \mathrm{~m}$ from the ground, and in case of multiple stems, all live tillers were also measured at $1.30 \mathrm{~m}$.

The first inventory was conducted in the T0 period, that is, before damming. The second inventory was made 2 years (T2) and the third, 4 years (T4) after damming. All inventories were carried out at the end of the rainy season (March-April) to standardize the sampling and to avoid dry season influence on the plant stem diameter due to dehydration. All samplings followed the same procedure as the first inventory (more information in Vale et al. 2013). The new individuals that met the inclusion criteria (recruits) were measured and identified. Mortality referred to standing dead trees or fallen trees.

\section{Diversity analysis}

We calculated the Shannon-Weaver diversity index (Shannon 1948) to measure changes in diversity over the three measurement periods (T0-T2-T4). We applied the Hutcheson $t$ test (Hutcheson 1970) to compare the richness between $\mathrm{T} 0-\mathrm{T} 2, \mathrm{~T} 2-\mathrm{T} 4$, and $\mathrm{T} 0-\mathrm{T} 4$ period in all forests. Moreover, we estimated the richness based on second-order Jackknife (Colwell 2005). This estimator was considered by Colwell and Coddington (1994) as one of the best predictors of richness.

\section{Dynamic rates analysis}

Each species was evaluated regarding dynamic rates in the T0-T2, T2-T4, and T0-T4 periods: mortality, recruitment, outgrowth, and ingrowth rates (we focused on species with at least 20 individuals, but all results are in the Additional file 1). Mortality (M) and recruitment (R) were calculated in terms of annual exponential rates (formulas in Sheil et al. 1995; Sheil et al. 2000). The outgrowth annual rates $(\mathrm{O})$ refer to basal area of dead trees plus dead branches and basal area of living trees (decrement) and ingrowth annual rates (I) refer to basal area of recruits plus growth in basal area of surviving trees (increment). To evaluate changes in the forest, we determined turnover rates for individuals and basal area through mortality-recruitment rates and outgrowth-ingrowth rates (Oliveira-Filho et al. 2007).

\section{Results}

Floristic and dynamic - general changes in species

In all three dry forests, the diversity index increased in the first 2 years and for the second year to the fourth year of measurement (Table 1). In DF1, the T2-T4 period showed more diversity changes than did T0-T2 (significant, see Table 1). Nevertheless, in DF2, the greatest diversity increase occurred in the T0-T2 period (significant, see Table 1). In SF the same difference in T0-T2 and T2-T4 was noted, but not significant in either period. The 4-year effect of damming on forests was the most notable. Comparing the T0-T4 period for all dry forest investigated, the Shannon diversity index increased significantly (Table 1), confirming the positive influence of soil moisture on richness and diversity.

The second-order Jackknife richness estimator predicted 62 in deciduous forest 1,81 in the deciduous forest 2 and 131 species in the semideciduous forest per hectare sampled in T0 (Fig. 2a-c). However, the estimated richness after impoundment increased for both deciduous forests in only 2 years of impact (62 to 74 in deciduous 1 and 81 to 91 in deciduous 2). For deciduous 1 , richness continued to increase and reached 85 species per hectare (Fig. 2a), but in deciduous 2, richness stabilized at 91 (Fig. 2b). Otherwise, there were no strong variations in the semideciduous forest after dam construction 
Table 1 Number of species and Shannon diversity index for three dry forests before (T0) and 2 (T2) and 4 years (T4) after dam construction in southeastern Brazil. Letters refer to the Hutcheson $t$ test, where same letters indicate same diversity; degrees of freedom $>500, p<0.05$

\begin{tabular}{lllllll}
\hline \multicolumn{4}{c}{ Arboreal component } \\
\hline & T0 & T2 & T4 & T0 & T2 & T4 \\
Deciduous 1 & 45 & 50 & 57 & $2.50 \mathrm{a}$ & $2.57 \mathrm{a}$ & $2.69 \mathrm{~b}$ \\
Deciduous 2 & 57 & 67 & 68 & $2.66 \mathrm{a}$ & $2.83 \mathrm{~b}$ & $2.89 \mathrm{~b}$ \\
Semideciduous & 89 & 91 & 93 & $3.43 \mathrm{a}$ & $3.48 \mathrm{ab}$ & $3.54 \mathrm{~b}$ \\
\hline
\end{tabular}

letter "a" refers to lower values and "b" refers to higher values, statistically significative.

and the richness values determined for $\mathrm{T} 2$ and $\mathrm{T} 4$ were similar (181 and 182, respectively-Fig. 2c).

In deciduous forest 1 (DF1), the new species found in T2 were Aspidosperma subincanum Mart. ex A. DC., Guapira areolata (Heimerl) Lundell, Guarea guidonia (L.) Sleumer, Luehea grandiflora Mart., Siparuna guianensis Aubl., Trema micrantha (L.) Blume, and Xylopia aromatica (Lam.) Mart., and in the T4, they were Inga vera Kunth, Jacaranda caroba, Margaritaria nobilis (Vell.) A. DC., Myrsine umbellata Mart., Trichilia elegans A. Juss., Xylopia brasiliensis Spreng., and Tocoyena formosa (Cham. \& Schltdl.) K. Schum. This last species was found in T0, but only as one tree, which died. However, two recruits were sampled in T4. Another species, Sterculia striata, was not found in T2 and T4.

In deciduous forest 2 (DF2), the new species found in T2 were Cedrela fissilis Vell., Eugenia florida DC., Genipa americana L., G. guidonia, L. grandiflora, Nectandra cissiflora Nees, Terminalia glabrescens Mart., Trichilia catigua A. Juss., T. elegans, Trichilia pallida Sw., and Zanthoxylum rhoifolium Lam. In T4, only two new species were found, i.e., Ceiba speciosa (A. St.-Hil.) Ravenna and Matayba guianensis Aubl. Otherwise, two species were not found, one in T2 (Aegiphila sellowiana Cham.) and another in the T4 period (Hymenaea courbaril L.).

The semideciduous forest (SF), however, changed little in richness. The new species sampled in T2 were Albizia niopoides (Spruce ex Benth.) Burkart, Heteropterys byrsonimifolia A. Juss., Machaerium hirtum (Vell.) Stellfeld, Psidium rufum DC., and Terminalia phaeocarpa Eichler, and in T4, they were Hirtella gracilipes (Hook. f.) Prance and Cecropia pachystachya Trécul. Otherwise, three species were not found in the T2 period, namely Dilodendron bipinnatum Radlk., Bauhinia rufa (Bong.) Steud., and Byrsonima laxiflora Griseb.

When we considered the occurrence of new species according to distance from the reservoir, it was notable that damming caused a rise in richness. Of the 34 new species (accounting for all forests), 28 were collected near the shore $(0-30 \mathrm{~m})$ and only 6 were not found in these patches, indicating a dam influence on the establishment of new species. Furthermore, these 6 species were located only far from the shore $(30-60 \mathrm{~m})$.

\section{Dynamic rates}

The dynamic rates confirmed the damming effects on the tree community, especially in the first 2 years exemplified for those species with 20 or more individuals. In this period, 7 of 10 species showed a dynamic rate of more than $10 \%$ per year (Table 2), values considered extremely high. In DF2, the same was observed for 17 species (20 or more individuals), where 15 had a dynamic rate of more than $10 \%$ per year (Table 3 ). However, the semideciduous species were more stable regarding species dynamics in the T0-T2 period. Only 5 of 20 species with more than 20 trees had a dynamic rate greater than $10 \%$ per year (Table 4 ).

These high dynamic rates in the first 2 years did not follow the same pattern in subsequent years. For the same species analyzed in the T0-T2 period, only one in DF1, four in DF2, and three in SF had a dynamic rate over $10 \%$ per year. This contrast in dynamic rates between T0-T2 and T2-T4 illustrate the damming effects on the entire community. Many species showed greater rates of mortality, recruitment, outgrowth, and ingrowth compared to communities (Fig. 3), and thus, the dam construction impact was substantially more intense in the first 2 years. These effects were more severe for both deciduous forests (Fig. 3) because more species displayed higher rates than did the community (and the community's rates were very high-Tables 2,3 , and 4 ). If we analyzed the entire period (T0-T4), the results did not seem significant, because only five species in DF1, nine in DF2, and four in SF had a dynamic rate greater than $10 \%$ per year. This result masked the true, marked changes that occurred in all forests, especially in the two deciduous forests, and therefore, monitoring every 2 years was essential for understanding damming effects (and consequently soil moisture increase) on dry seasonal forests.

\section{Discussion}

\section{Richness and diversity increase}

A surprising finding of this study was the quick changes in the richness and diversity in the three dry seasonal forests in communities, mainly on deciduous forests. According to the richness estimator, an increase in forest richness by 10 species per hectare could be seen in only 2 years of damming, a great increase considering that we only included trees at least $5 \mathrm{~cm}$ in diameter. Many studies on impacted forests have demonstrated structural changes a few years after great disturbances such as storms (Laurance et al. 2006; Pascarella et al. 2004), fragmentation due to edge effects (Laurance et al. 2006), 


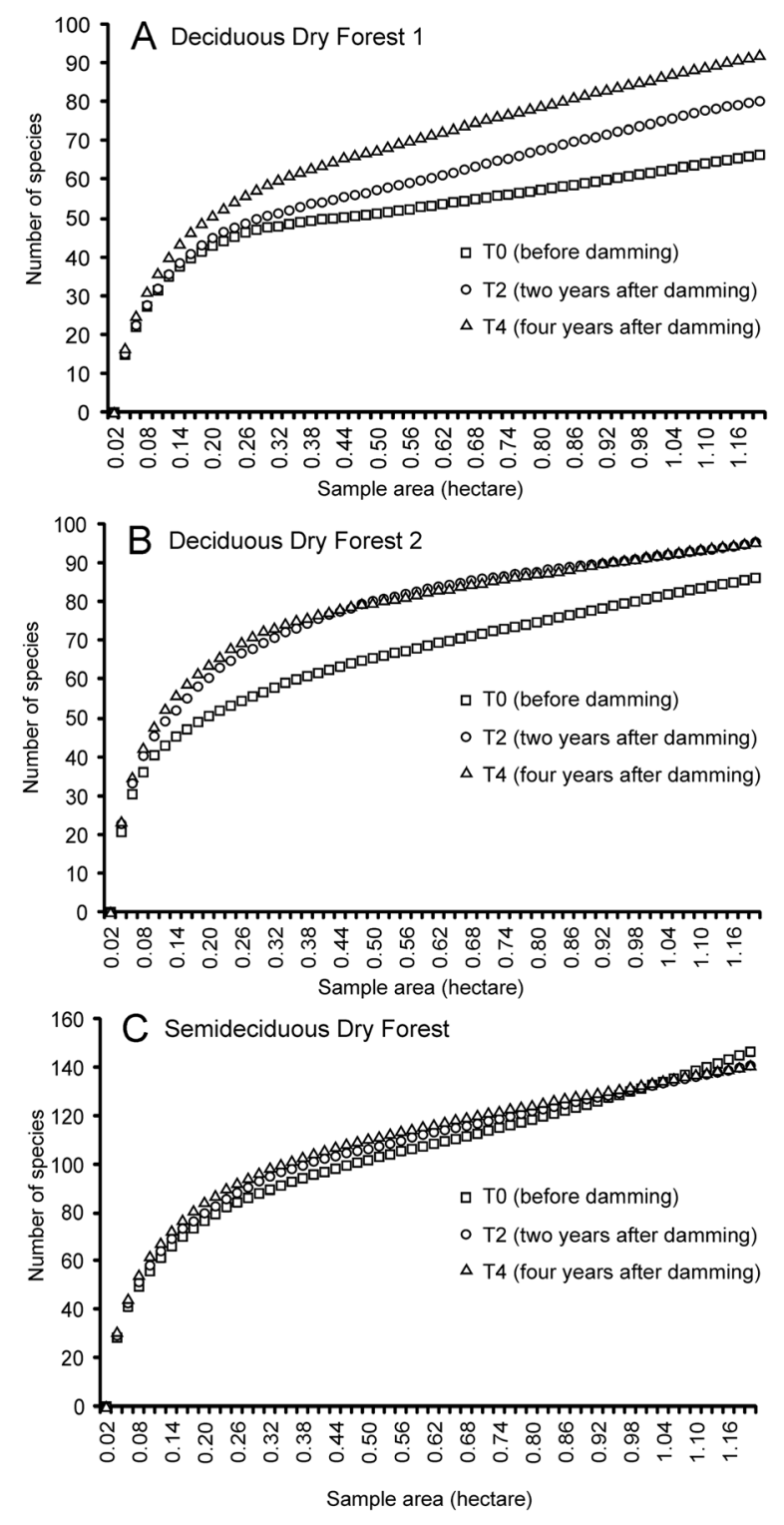

Fig. 2 Rarefaction cumulative number of species using Jackknife estimator for three periods in three dry seasonal forests (A, B, and C). Triangles indicate the period before damming; circles indicate the period 2 years after damming; and squares represent 4 years after damming

logging (Guariguata et al. 2008), and severe dry periods (Chazdon et al. 2005), but still with forest recovery of structure and composition over the years (Chazdon et al. 2007). In general, only long-term studies have shown changes in tree species and their probable consequences for the community (Laurance et al. 2006), because trees could be long-lived and because changes resulting from disturbances would be gradual. This rapid increase in richness and diversity found for all dry forests analyzed support the hypothesis of great changes caused by dam construction, even in the tree community. The main factor was the increase in the amount of water available, a barrier for many species to growth in the dry season before the damming (Vale et al. 2013). With water available in dry periods after impoundment (Vale et al. 2013), there was no water restriction and more plant species could grow enough to meet the inclusion criteria.

Most of the new species recruited probably were already present in the community as small individuals or saplings with deficiency in growth due to water stress. Summarizing these new species sampled, at least 20 are water-associated species, found in non-Amazonian riparian forests (Rodrigues and Nave 2000), humid Atlantic Forest (Oliveira and Fontes 2000), or even distributed in wet environments of riparian (gallery) forests (Oliveira-Filho and Ratter 2002) or flooded forests (Silva et al. 2007). Hence, prolonged dry periods could act as a negative filter for these species in the original dry conditions, killing them or at least hindering their establishment. The rise in soil moisture due to dam construction (Gusson et al. 2011) breaks the marked seasonality of soil moisture for these forests, favoring the establishment of water-associated species.

Is important to note that the new conditions created by damming are not transitory. Thus, other tree species can be established in this community over the years, and the community will never return to its original state. Germination is influenced by water (Breshears et al. 1998), and some species would have better conditions to stabilize. Even fruits and seeds dispersed from other areas should also increase species richness. The short period of monitoring and the inclusion criteria (only trees five or more centimeters in diameter were sampled) make it difficult to make these affirmations about germination and dispersion influences on richness. However, a regeneration work in these areas shows distinct seedling and sapling responses of the two most important species in these forests (Anadenanthera colubrina and Myracrodruon urundeuva) demonstrated that $M$. urundeuva had a more negative response than $\operatorname{did} A$. colubrina to increased soil water (Gusson et al. 2011), verifying the effects on germination. Moreover, other dam studies have compared free-flowing rivers with regulated rivers and have shown some positive effects of damming on plant richness due to dispersion (Jansson et al. 2000) and germination (Andersson et al. 2000). The rise in richness and diversity should be treated with caution. The increase in richness and diversity will never overcome the loss of species drowned by the damming. This increase in richness may be treated as one more impact of dams on the flora.

Studies in temperate environments affected by dams have found species changes (Jansson et al. 2000; Nilsson et al. 2002) but have concluded that both richness and diversity are not the most sensitive indicators of effects 
Table 2 Tree species parameters and dynamic rates for a deciduous forest (Deciduous forest 1 ) in Southeastern Brazil. T0 = before dam construction, $\mathrm{T} 2=2$ years after damming, $\mathrm{T} 4=4$ years after damming, $\mathrm{M}=$ mortality, $\mathrm{R}=$ recruitment, $\mathrm{O}=$ outgrowth, $\mathrm{I}=$ ingrowth. Only species with at least 20 individuals are shown

\begin{tabular}{|c|c|c|c|c|c|c|c|c|c|c|c|c|c|c|c|c|c|c|}
\hline \multirow{2}{*}{$\frac{\text { Deciduous forest } 1}{\text { Species }}$} & \multicolumn{3}{|c|}{ Number of individuals } & \multicolumn{3}{|c|}{ Basal area } & \multicolumn{4}{|c|}{ Dynamic rates T0-T2 } & \multicolumn{4}{|c|}{ Dynamic rates T2-T4 } & \multicolumn{4}{|c|}{ Dynamic rates T0-T4 } \\
\hline & T0 & $\mathrm{T} 2$ & $\mathrm{~T} 4$ & T0 & $\mathrm{T} 2$ & $\mathrm{~T} 4$ & M & $\mathrm{R}$ & $\mathrm{O}$ & 1 & M & $\mathrm{R}$ & $\mathrm{O}$ & 1 & M & $\mathrm{R}$ & $\mathrm{O}$ & 1 \\
\hline Acacia polyphylla & 40 & 39 & 35 & 25 & 0.25 & 0.28 & 19.4 & 18.4 & 19.2 & 19.9 & 5.3 & 0.0 & 3.4 & 8.5 & 13.9 & 11.0 & 12.6 & 15.3 \\
\hline brina & 1 & 1 & 187 & 3.18 & 4. & 5 & 1 & 10.9 & 2 & 19.5 & 4.8 & 9.0 & 4.8 & 9.2 & 4.0 & 10.5 & 5.0 & 15.7 \\
\hline Bauhi & 28 & 30 & 29 & 0.09 & 0.1 & 0.13 & 3.6 & 6.9 & 3.5 & 18.3 & 5.1 & 3.5 & 4.8 & 6.4 & 4.8 & 5.6 & 5.4 & 13.7 \\
\hline Car & 2 & 89 & o & 1.23 & 1. & 10 & 6 & 4.6 & 6 & 4. & 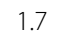 & 0.0 & 3.2 & 2.8 & 1.0 & 2.4 & 4.9 & 4.0 \\
\hline Casearia rupestris & 24 & 21 & 19 & 0.18 & 0.17 & 0.18 & 13.4 & 7.4 & 11.4 & 8.6 & 4.9 & 0.0 & 5.5 & 8.9 & 9.6 & 4.2 & 9.0 & 9.3 \\
\hline Guazu & 19 & 22 & 23 & 0.11 & $0.2 J$ & 0.23 & 0.0 & 1.1 & 2.0 & 19.0 & f.7 & 6.7 & 2.9 & 9.4 & $2 . r$ & 1.0 & J.J & 政 \\
\hline Myracrodruon & 279 & 238 & 199 & 5.33 & 5.61 & 5.44 & 8.2 & 0.6 & 3.7 & 6 & 9.0 & 0.5 & 4.2 & 2.7 & 8.7 & 0.6 & 4.2 & 4.7 \\
\hline Piptadeni & 71 & 0 & (9) & 0 & 1.02 & I. & 11.2 & 23.6 & 16.9 & 26.5 & 1.0 & 8.4 & 14.2 & 15 & 11.8 & 18.8 & 22.8 & 27.9 \\
\hline Platypodium elegans & 21 & 21 & 20 & 0.58 & 0.65 & 0.72 & 2.4 & 2.4 & 6.4 & 11.9 & 2.4 & 0.0 & 0.5 & 5.5 & 2.5 & 1.3 & 3.6 & 8.8 \\
\hline Tabebuia roseoalba & 246 & 7 & 231 & 286 & 3.05 & 312 & 3.9 & 21 & 21 & 5.5 & 30 & 1.7 & 1.9 & 3.1 & 3.5 & 2.0 & 2.3 & 4.4 \\
\hline tire community & 1124 & 1136 & 1133 & 16.80 & 19.16 & 20.54 & 6.5 & 7.1 & 4.9 & 11.0 & 4.9 & 4.7 & 4.0 & 6.6 & 6.1 & 6.3 & 5.0 & 9.2 \\
\hline
\end{tabular}

of flow regulation (Dynesius et al. 2004). Our results, however, suggest high modification in both richness and diversity after only 4 years of impact. The impacts on the species pool were probably high due the high biodiversity in tropical environments, and several shifts in species should be expected in any overflow in the tropics. This is a key problem because the most diverse tropical systems are affected by dams (Nilsson et al.
2005) and this represent a high risk to biodiversity because all forests in the tropics that are subjected to similar flooding after damming tend to show high species chances.

It is difficult to imagine how damming affects forest communities all over the world, but the changes shown here point to a dramatic scenario with huge modifications. Moreover, the damming influence on recruitment

Table 3 Tree species parameters and dynamic rates for a deciduous forest (Deciduous forest 2 ) in Southeastern Brazil. T0 = before dam construction, $\mathrm{T} 2=2$ years after damming, $\mathrm{T} 4=4$ years after damming, $\mathrm{M}=$ mortality, $\mathrm{R}=$ recruitment, $\mathrm{O}=$ outgrowth, $\mathrm{I}=$ ingrowth. Only species with at least 20 individuals are shown

\begin{tabular}{|c|c|c|c|c|c|c|c|c|c|c|c|c|c|c|c|c|c|c|}
\hline \multirow{2}{*}{$\frac{\text { Deciduous forest } 2}{\text { Species }}$} & \multicolumn{3}{|c|}{ Number of individuals } & \multicolumn{3}{|c|}{ Basal area } & \multicolumn{4}{|c|}{ Dynamic rates T0-T2 } & \multicolumn{4}{|c|}{ Dynamic rates $\mathrm{T} 2-\mathrm{T} 4$} & \multicolumn{4}{|c|}{ Dynamic rates T0-T4 } \\
\hline & T0 & $\mathrm{T} 2$ & $\mathrm{~T} 4$ & T0 & $\mathrm{T} 2$ & T4 & $M$ & $R$ & $\mathrm{O}$ & 1 & $M$ & $\mathrm{R}$ & $\mathrm{O}$ & 1 & $M$ & $R$ & $\mathrm{O}$ & 1 \\
\hline Allophylus racemosus & 13 & 22 & 22 & 05 & 0.08 & 0.09 & 3.9 & 26.1 & 3.1 & 23.8 & 2.3 & 2.3 & 3.3 & 7.4 & 4.1 & 15.9 & 4.5 & 17.1 \\
\hline Aloysia virgata & 43 & 35 & 25 & 0.20 & 0.16 & 0.12 & 12.4 & 2.9 & 14.3 & 5.3 & 15.5 & 0.0 & 15.5 & 1.7 & 14.5 & 2.1 & 15.9 & 4.6 \\
\hline Anadenanthera colubrina & 68 & 88 & 93 & 2.20 & 2.53 & 2.97 & 3.7 & 15.4 & 11.9 & 17.8 & 1.7 & 4.4 & 0.4 & 8.2 & 3.1 & 10.4 & 6.4 & 13.2 \\
\hline Aspidosperma parvifolium & 20 & 23 & 24 & 34 & 0.19 & 0.38 & 0.0 & 6.7 & 0.0 & 11.1 & 2.2 & 4.3 & 5.2 & 32.3 & 1.3 & 5.7 & 1.5 & 23.0 \\
\hline Campomanesia velutina & 27 & 31 & 32 & 0.13 & 0.16 & 0.17 & 1.9 & 8.4 & 3.3 & 12.0 & 0.0 & 1.6 & 1.9 & 5.5 & 0.9 & 5.1 & 2.9 & 9.1 \\
\hline Casearia gossypiosperma & 21 & 32 & 37 & 08 & 0.13 & 0.16 & 0.0 & 19.0 & 0.1 & 21.9 & 0.0 & 7.0 & 0.4 & 8.9 & 0.0 & 13.2 & 0.4 & 15.8 \\
\hline Casearia rupestris & 165 & 149 & 136 & 0.88 & 0.93 & 0.89 & 9.2 & 3.8 & 8.6 & 11.0 & 4.9 & 0.4 & 4.3 & 2.2 & 7.3 & 2.3 & 7.1 & 7.2 \\
\hline Celtis is & 29 & 31 & 27 & 25 & 0.25 & 0.22 & 5.3 & 8.4 & 12.6 & 13.2 & 6.7 & 0.0 & 13.1 & 7.8 & 6.7 & 5.0 & 15.3 & 13.0 \\
\hline Coccoloba mollis & 33 & 31 & 32 & 0.23 & 0.23 & 0.24 & 6.3 & 1.6 & 11.9 & 11.2 & 1.6 & 3.2 & 4.6 & 6.7 & 4.0 & 2.4 & 9.0 & 9.6 \\
\hline Dilodendrc & 46 & 45 & 46 & 35 & .40 & 0 & 2.2 & 1 & 3.9 & 16.2 & 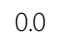 & .1 & 0.4 & 7.8 & 1 & 1 & 2.2 & 12 \\
\hline Guazuma ulmifolia & 478 & 430 & 414 & 4.75 & 5.08 & 5.54 & 7.6 & 2.1 & 5.7 & 8.7 & 2.6 & 0.6 & 2.7 & 6.7 & 5.2 & 1.4 & 4.5 & 8.0 \\
\hline Handroanthus vellozoi & 20 & 18 & 17 & 0.16 & 0.16 & 0.17 & 5.1 & 0.0 & 3.7 & 6.6 & 2.8 & 0.0 & 1.0 & 3.2 & 4.0 & 0.0 & 2.4 & 5.0 \\
\hline Inga sessilis & 170 & 202 & 200 & 1.14 & 1.45 & 1.53 & 4.5 & 11.8 & 6.9 & 17.1 & 3.0 & 2.5 & 4.0 & 6.5 & 4.2 & 7.7 & 6.4 & 12.8 \\
\hline Lonchocarp & 32 & 52 & 54 & 0.27 & 0.44 & 0.54 & 3.2 & 21.6 & 3.4 & 23.9 & 2.9 & 4.7 & 0.9 & 10.2 & 4.2 & 14.4 & 2.5 & 17.6 \\
\hline Machaerium brasiliensis & 22 & 24 & 26 & 0.11 & 0.17 & 0.20 & 0.0 & 4.3 & 0.0 & 20.3 & 0.0 & 3.9 & 0.1 & 9.1 & 0.0 & 4.1 & 0.0 & 14.9 \\
\hline Myracrodruon urundeuva & 225 & 208 & 197 & 3.75 & 4.10 & 4.34 & 5.5 & 1.0 & 4.3 & 8.6 & 3.4 & 0.5 & 2.1 & 4.6 & 4.5 & 0.8 & 3.4 & 6.8 \\
\hline Rhamnidium elaeocarpum & 34 & 39 & 37 & 0.20 & 0.25 & 0.26 & 1.5 & 8.0 & 1.5 & 11.9 & 2.6 & 0.0 & 4.4 & 5.5 & 2.3 & 4.3 & 3.6 & 9.3 \\
\hline Entire community & 1626 & 1670 & 1649 & 18.03 & 20.23 & 21.75 & 6.0 & 6.9 & 5.9 & 11.7 & 3.0 & 2.3 & 3.3 & 6.7 & 4.8 & 4.8 & 5.1 & 9.7 \\
\hline
\end{tabular}


Table 4 Tree species parameters and dynamic rates for a semideciduous forest (SF) in Southeastern Brazil. T0 = before dam construction, T2 = 2 years after damming, T4 = 4 years after damming, $\mathrm{M}=$ mortality, $\mathrm{R}=$ recruitment, $\mathrm{O}=$ outgrowth, I= ingrowth . Only species with at least 20 individuals are shown

\begin{tabular}{|c|c|c|c|c|c|c|c|c|c|c|c|c|c|c|c|c|c|c|}
\hline \multirow{2}{*}{$\begin{array}{l}\text { Semideciduous forest } \\
\text { Species }\end{array}$} & \multicolumn{3}{|c|}{ Number of individuals } & \multicolumn{3}{|c|}{ Basal area } & \multicolumn{4}{|c|}{ Dynamic rates T0-T2 } & \multicolumn{4}{|c|}{ Dynamic rates T2-T4 } & \multicolumn{4}{|c|}{ Dynamic rates T0-T4 } \\
\hline & T0 & $\mathrm{T} 2$ & $\mathrm{~T} 4$ & T0 & $\mathrm{T} 2$ & $\mathrm{~T} 4$ & M & $\mathrm{R}$ & $\mathrm{O}$ & I & M & $\mathrm{R}$ & $\mathrm{O}$ & I & M & $\mathrm{R}$ & $\mathrm{O}$ & I \\
\hline Apuleia leiocarpa & 26 & 29 & 33 & 0.82 & 0.93 & 1.01 & 0.0 & 5.3 & 0.0 & 6.3 & 0.0 & 6.3 & 0.1 & 3.7 & 0.0 & 5.8 & 0.1 & 5.0 \\
\hline Aspidosperma discolor & 121 & 119 & 127 & 2.31 & 2.59 & 2.90 & 2.9 & 2.1 & 2.8 & 8.2 & 0.0 & 3.2 & 0.1 & 5.6 & 1.5 & 2.7 & 1.4 & 6.9 \\
\hline Astronium nelson-rosae & 99 & 104 & 107 & 1.13 & 1.27 & 1.40 & 2.0 & 4.4 & 1.9 & 7.4 & 0.5 & 1.9 & 0.5 & 5.3 & 1.3 & 3.2 & 1.2 & 6.4 \\
\hline Callisthene major & 55 & 56 & 56 & 4.21 & 4.45 & 4.51 & 2.8 & 3.6 & 0.8 & 3.5 & 2.7 & 2.7 & 2.0 & 2.7 & 2.8 & 3.3 & 1.5 & 3.2 \\
\hline Casearia gossypiosperma & 19 & 23 & 24 & 0.22 & 0.26 & 0.28 & 0.0 & 9.1 & 0.3 & 9.4 & 0.0 & 2.1 & 0.0 & 3.8 & 0.0 & 5.7 & 0.2 & 6.6 \\
\hline Casearia grandiflora & 136 & 115 & 119 & 0.99 & 0.89 & 0.91 & 11.7 & 4.4 & 12.3 & 7.7 & 3.1 & 4.3 & 4.3 & 5.4 & 7.6 & 4.5 & 8.7 & 6.9 \\
\hline Cheiloclinium cognatum & 103 & 100 & 105 & 0.64 & 0.62 & 0.73 & 5.0 & 3.6 & 7.4 & 6.1 & 0.5 & 2.9 & 1.5 & 8.8 & 2.8 & 3.3 & 4.6 & 7.5 \\
\hline Copaifera langsdorffii & 81 & 76 & 77 & 6.74 & 7.12 & 7.64 & 3.1 & 0.0 & 2.5 & 5.2 & 0.0 & 0.7 & 0.0 & 3.5 & 1.6 & 0.3 & 1.3 & 4.3 \\
\hline Cordiera sessilis & 152 & 137 & 125 & 1.14 & 1.05 & 1.01 & 6.1 & 1.1 & 7.8 & 3.9 & 4.5 & 0.0 & 5.5 & 3.8 & 5.3 & 0.6 & 6.9 & 4.1 \\
\hline Diospyrus hispida & 25 & 21 & 21 & 0.57 & 0.52 & 0.56 & 8.3 & 0.0 & 12.6 & 8.4 & 0.0 & 0.0 & 0.1 & 4.1 & 4.3 & 0.0 & 6.6 & 6.3 \\
\hline Duguetia lanceolata & 54 & 56 & 60 & 0.46 & 0.50 & 0.55 & 4.7 & 6.5 & 5.5 & 9.4 & 0.9 & 4.3 & 1.8 & 6.9 & 2.9 & 5.4 & 3.9 & 8.3 \\
\hline Heisteria ovata & 35 & 34 & 33 & 0.26 & 0.27 & 0.31 & 5.9 & 4.5 & 6.7 & 8.2 & 1.5 & 0.0 & 0.5 & 6.7 & 3.8 & 2.4 & 3.7 & 7.5 \\
\hline Luehea grandiflora & 30 & 33 & 40 & 0.30 & 0.29 & 0.30 & 5.1 & 9.5 & 9.8 & 8.1 & 1.5 & 10.6 & 6.6 & 7.3 & 3.5 & 10.2 & 8.9 & 8.3 \\
\hline Mabea fistulifera & 25 & 27 & 32 & 0.53 & 0.59 & 0.57 & 6.2 & 9.7 & 2.4 & 8.0 & 3.8 & 11.6 & 8.5 & 6.7 & 5.4 & 11.1 & 6.3 & 8.2 \\
\hline Micropholis venulosa & 33 & 31 & 33 & 0.56 & 0.65 & 0.75 & 4.7 & 1.6 & 5.0 & 12.1 & 0.0 & 3.1 & 0.2 & 6.5 & 2.4 & 2.4 & 2.7 & 9.4 \\
\hline Myrcia floribunda & 101 & 105 & 104 & 0.80 & 0.84 & 0.92 & 2.5 & 4.4 & 5.9 & 8.2 & 1.4 & 1.0 & 1.2 & 5.6 & 2.0 & 2.8 & 3.7 & 7.0 \\
\hline Protium heptaphyllum & 37 & 37 & 39 & 0.53 & 0.56 & 0.60 & 5.6 & 5.6 & 2.1 & 5.4 & 1.4 & 3.9 & 1.4 & 4.6 & 3.6 & 4.8 & 1.8 & 5.1 \\
\hline Siparuna guianensis & 16 & 16 & 24 & 0.06 & 0.05 & 0.14 & 33.9 & 33.9 & 30.9 & 24.5 & 3.2 & 20.9 & 7.7 & 9.7 & 21.7 & 29.3 & 22.9 & 10.1 \\
\hline Siphoneugena densiflora & 19 & 22 & 23 & 0.19 & 0.21 & 0.23 & 0.0 & 7.1 & 0.5 & 4.6 & 2.3 & 4.4 & 0.8 & 5.3 & 1.3 & 5.9 & 0.7 & 5.0 \\
\hline Terminalia glabescens & 73 & 71 & 77 & 0.72 & 0.79 & 0.92 & 8.6 & 7.3 & 8.1 & 11.9 & 1.4 & 5.3 & 1.1 & 8.5 & 5.2 & 6.4 & 4.8 & 10.4 \\
\hline Entire community & 1501 & 1489 & 1573 & 27.99 & 29.16 & 31.66 & 5.5 & 5.2 & 4.5 & 6.5 & 1.6 & 4.2 & 1.4 & 5.5 & 3.7 & 4.8 & 3.1 & 6.1 \\
\hline
\end{tabular}

of water-associated species was strongest in patches near the river (0-30 $\mathrm{m}$ from the shore), which was twice that of those sampled farther from shore (30-60 m). Thus, damming effects on the community and on some species especially have been concentrated near the reservoir (Vale et al. 2013), just the main area for conservation efforts through ecological services such as with regard to soil protection against erosion and siltation (Guo et al. 2007; Hubble et al. 2010), aquatic fauna and corridor for fauna movements (Gundersen et al. 2010), and pathways for plant dispersion (Naiman and Decamps 1997; Nilsson and Berggren 2000). These areas that become situated close to the artificial lakeshore showed high impact and should be monitored for several years, so that we learn more about the many implications for ecosystems.

Water restriction is a common event for seasonal environments, but it is harsher for deciduous than semideciduous forests. The mountainous terrains with high slope and rocky soils in deciduous forests (Oliveira-Filho and Ratter 2002) facilitate the water flow in rainy periods and hinder water infiltration (Baker et al. 2002). In the semideciduous forest, water stress is less intense due to more clayey soils and less sloped terrain, and hence, fewer new species are found.

Due to being in a more water-stressed environment, deciduous forests have stronger deciduousness during dry season than do semideciduous forests. With dam construction, the proximity of the forest to the water table increases subsoil water reserves, which is the ecophysiological basis for evergreen maintenance (Borchert 1998; Nepstad et al. 1994). Therefore, in the deciduous forest, the environment during the dry season becomes milder, facilitating the growth of evergreen species (most new species collected were evergreen). Evergreen species have more advantages when the environment is not water deficient. Deciduous species have more photosynthetic capacity (Reich et al. 2003) but lose part of the carbon acquired due to leaf fall. On the other hand, evergreen species do not lose much carbon during the dry season and are therefore photosynthetically active during the dry season (Chabot and Hicks 1982). In general, evergreen species have deep roots with more secondary and lateral roots (Markesteijn et al. 2010), and thus, it would be difficult to 


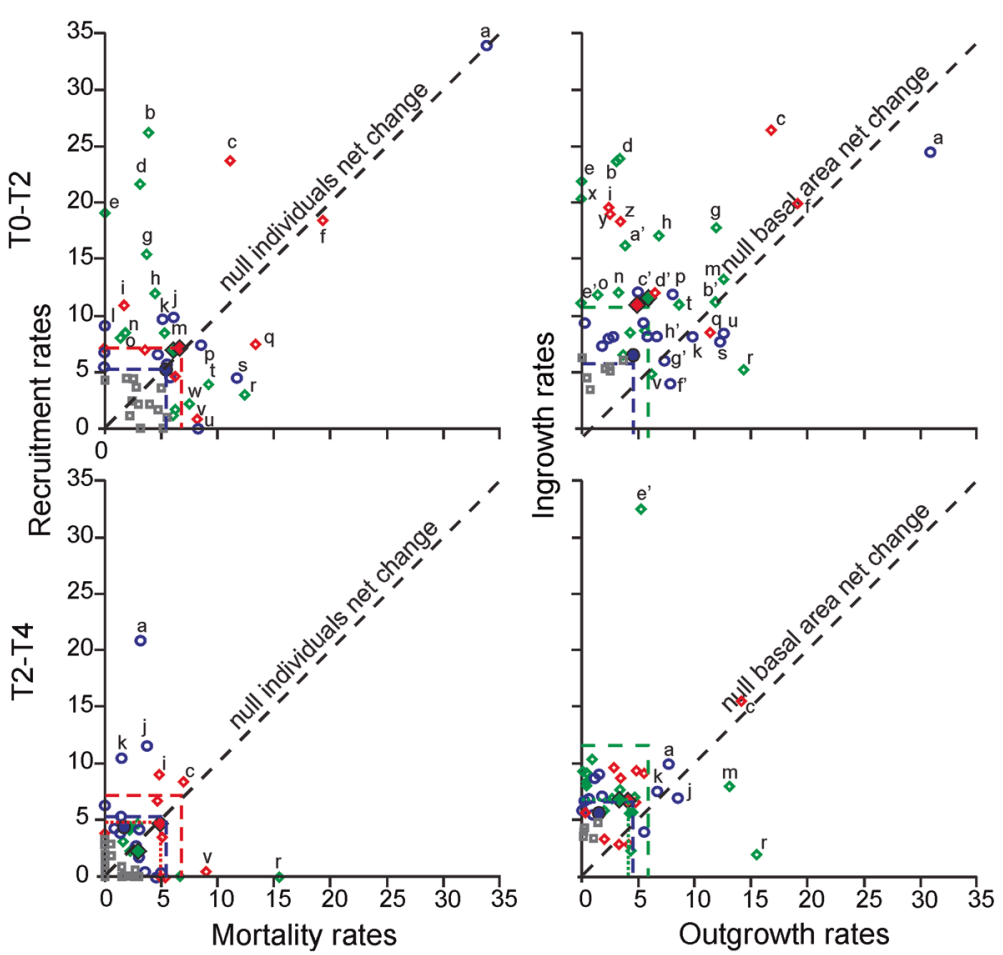

Fig. 3 Comparison of recruitment/mortality ( $a$ and $c$ ) and ingrowth/outgrowth ( $b$ and $d$ ) rates in species with 20 or more individuals in dry forests in Southeastern Brazil. $a$ and $b$ are species from a dry deciduous forest and $c$ and $d$ are species from dry semideciduous forests. Blue circles $=$ semideciduous forest species; green diamonds = deciduous forest 1 species; red diamonds = deciduous forest 2 species; green squares = species with low dynamic rates even in the T0-T2 period; closed blue circles = entire semideciduous forest; closed green diamonds = entire deciduous forest 1; closed red diamonds = entire deciduous forest 2; dashed lines indicate the entire community rates in T0-T2 period. $a=$ Siparuna guianensis; $b=$ Allophylus racemosus; $c=$ Piptadenia gonoacantha; $d=$ Lonchocarpus cultratus; $e=$ Casearia gossypiosperma; $f=$ Acacia polyphylla; $g=$ Anadenanthera colubrina; $h=$ Inga sessilis; $i=$ Anadenanthera colubrina; $j=$ Mabea fistulifera; $k=$ Luehea grandiflora; $I=$ Casearia gossypiosperma; $m=$ Celtis iguanaea; $n=$ Campomanesia velutina; $o=$ Rhamnidium elaeocarpum; $p=$ Terminalia glabescens; $q=$ Casearia rupestris; $r=$ Aloysia virgata; $s=$ Casearia grandiflora; $t=$ Casearia rupestris; $u=$ Dyospirus hispida; $v=$ Myracrodruon urundeuva; $w=$ Guazuma ulmifolia; $x=$ Machaerium brasiliensis; $y=$ Guazuma ulmifolia; $z=$ Bauhinia ungulata; $a^{\prime}=$ Dilodendron bipinnatum; $b^{\prime}=$ Coccoloba mollis; $c^{\prime}=$ Micropholis venulosa; $d^{\prime}=$ Platypodium elegans; $e^{\prime}=$ Aspidosperma olivaceum; $f^{\prime}=$ Cordiera sessilis; $g^{\prime}=$ Cheiloclinium cognatum; $h^{\prime}=$ Duguetia lanceolata

maintain root biomass with less carbon gain during dry seasons (Wright and Vanschaik 1994).

However, with water supply all over the year, photosynthesis had no limiter and evergreen plants could present high growth rates. Thus, in the longterm we expected a conversion of physiognomies near the riverbed, of an original deciduous forest to a more evergreen environment (a semideciduous forest, but still with marked deciduousness due longlived deciduous trees). What about new deciduous species found? Of all these "new-deciduous species," only three showed intermediate- to high-density wood (greater than 0.65 g. $\mathrm{cm}^{-3}$ ). Deciduous trees with lower wood density are more vulnerable to drought-induced embolism and cavitation (Choat et al. 2003; Choat et al. 2005), and thus, intense dry periods tend to be more negative for low-density wood deciduous plants (Markesteijn et al. 2010). With rise in soil moisture, the risk of low water problems for sap transportation is reduced; plant fitness and survival in the new conditions are favored. Thus, low-density wood was favored.

\section{"Riparian Effect"}

The rainfall regime and groundwater depths strongly influence species composition, community structure, and biological diversity (Ehleringer and Dawson 1992; Munoz-Reinoso 2001; Naiman and Decamps 1997), and a water-stressed environment can raise the richness and diversity of trees after water availability changes (Xu et al. 2009). On a global scale, humid forests have more biodiversity (Gaston 2000) in places without energy restriction, such as the tropics (O'Brien et al. 2000). Considering that the energy in these systems did not vary in the forests studied, the clear factor that enhanced richness was the change of a "common dry forest" to an "artificial riparian dry forest" due to increased soil moisture (the so-called "Riparian Effect"). 
Riparian forests are a transition zone between land and aquatic systems and support more plant richness than surrounding areas (Naiman and Decamps 1997; Nilsson and Berggren 2000) because they have flora associated with humid and dryer patches. The increase in richness and diversity, however, will not mean a "total" conversion of these dry forests into a typical riparian forest due to the maintenance of most of the species in the community, and a few species are lost. Riparian forests are species richness systems (Rodrigues and Nave 2000), due to the high heterogeneity, such as floods (Lopes and Schiavini 2007), distinct water flow (Jansson et al. 2000), and great soil moisture variations (Rodrigues et al. 2010), and despite that new species appeared, some characteristics of the original forest were constant.

Some of these "heterogeneity creators" in a natural riparian forest did not occur in the three forests analyzed here. First, floods did not occur because dam flow was controlled by an upstream dam, and thus the water table did not vary and soil moisture near stream would have few changes over subsequent years. Flood frequency and variations in water table depth increases habitat complexity (Naiman and Decamps 1997), creating conditions for the growth of different species (Lopes and Schiavini 2007). Second, the new artificial lake created did not have a water current, and thus the sediment and seed deposition from upstream plants would not occur. Flow regime influences species composition and distribution on a small scale (Bendix and Hupp 2000; Hughes and Rood 2003), because many seeds are dispersed by hydrochory (Jansson et al. 2000) and because soil deposition creates patches with distinct soil infiltration and nutrients (Rodrigues et al. 2010), increasing patches with environmental heterogeneity for the establishment of different species. Therefore, free-flowing rivers have more species-richness than regulated ones after long periods (Dynesius et al. 2004; Nilsson et al. 1997).

This "Riparian Effect" occurred in the three dry forests studied, not only enhancing richness and diversity but also leading to a marked exchange of individuals, due to high mortality and recruitment. There was little change in the total number of individuals, due to a balance in recruitment and death of trees; however, because of an imbalance after damming occurred, some species showed high recruitment rates and low mortality against species that were very negatively affected, with mortality rates higher than recruitment. Even a little soil moisture change may induce vegetation changes (Nilsson and Svedmark 2002), and increased soil water then causes different responses in species. On the one hand, water could kill roots by oxygen stress and consequently anoxia (Vartapetian and Jackson 1997; White 2007) and upland plants usually are intolerant to a riparian environment (Johnson 1994; Nilsson and Berggren 2000). On the other hand, it can break the intense dry seasonal period and enhance plant growth.

The scenario was an unstable period with intense tree changes and several consequences for species a few years after damming. Unstable periods occur after strong perturbation and some conclusions were difficult to make, but it is clear that most important species did not respond equally and those very negatively affected should not be used in the management of areas with similar impacts.

\section{Times of record assessment}

Not only were there a range of responses according to forest type (species in semideciduous forest responded less intensely to the effects of the dam), since the responses were concentrated in the first 2 years after impoundment, but also most species showed fewer changes in the T2-T4 period in all three forests, demonstrating that damming impacts tended to stabilize a few years after impoundment. Works with other taxa, such as macrophytes and insects, after damming (Fearnside 2005; Moura Júnior et al. 2011; Patz et al. 2000) have demonstrated that intense changes occur after dam construction but tend to stabilize over years (Lima et al. 2002). Even abiotic changes, such as carbon emission, were concentrated in the first years after damming (Fearnside 2002).

Hence, the analysis every 2 years was necessary and satisfactory in representing the scenario after damming, with marked changes just after impact followed by a stabilization. The damming effect for many species would have been masked, if analyzed only in the T0-T4 period because rates in $\mathrm{T} 2-\mathrm{T} 4$ were three to more than 10 times smaller for these species. Moreover, we avoided error associated with tree hydration when measurements are made in different seasons of the years (Phillips et al. 2004), because all measurements (T0, T2, and T4) were carried out at the end of the rainy season (March-April), increasing the reliability of the results. The measurement interval also affects dynamic rates (Phillips et al. 2004), but the rate differences for species between T0-T2 and T0-T4 were too high (frequently more than 5\% per year) to infer that the 2 or 4 years caused such great effects on rates. Finally, the rates could be influenced by the number of individuals for a species, and according to our criteria for analysis, we considered only species with 20 or more individuals to minimize this problem, resulting in many general tendencies.

\section{Conclusions}

With dam construction, the proximity of the forest to the water table increases subsoil water reserves and break the intense dry seasonal period. This disturbance is permanent, and is transforming the dry forests into an artificial riparian forest, however with less species and 
heterogeneity than it. We named this process of "Riparian Effect". This Riparian Effect is reorganizing forest structure with establishment of many water-associated species and increase of the forest basal area because the water supply improves tree growth, increasing basal area in many trees, which become thicker. Dams creates a permanent landscape alteration and changes in these forests will occur for several years and are more notable in the first two years after damming, however the changes in deciduous forest are more remarkable than in semideciduous forests. This paper helps understanding the impacts of damming on seasonal forests. Undoubtedly, not all changes in these forests can be documented, but it's clear that the damming impacts are very significant and deserve further study.

\section{Additional file}

Additional file 1: Tree species parameters and dynamic rates to three Dry Forests (Deciduous Forest 1 - DF1, Deciduous Forest 2 DF2 and Semideciduous Forest SF) in southearn Brazil. T0 = before dam construction, $\mathrm{T} 2$ = two years after damming, $\mathrm{T} 4$ = four years after damming, $\mathrm{M}=$ mortality, $\mathrm{R}=$ recruitment, $\mathrm{O}=$ outgrowth, $\mathrm{I}=$ ingrowth. Only species with less than 20 individuals are shown.

\section{Competing interests}

The authors declare that they have no competing interests.

\section{Authors' contributions}

VSV wrote the manuscript. VSV and IS participated in the design of the study. VSV, IS, JAPJ, APO and AEG participated in the field works and revised the manuscript. JAPJ corrected the English language. VSV, JAPJ, APO and AEG made the statistical analysis. VSV, statistical analyzes and wrote the manuscript.

\section{Acknowledgements}

The authors thank the Foundation for Research Support of the State of Minas Gerais (FAPEMIG), CAPES (Coordination for the Development of Higher Education Personnel, Process 2498/09-0), and PACCSS-FAPEMIG (Process CRA-30058-12) for financial support for financial support. Dr. A. Leyva helped with English editing of the manuscript.

\section{Author details}

${ }^{1}$ Universidade Estadual de Goiás (State University of Goiás) - Campus Ipameri, CEP 75780-000, Ipameri, Goiás, Brasil. ²Laboratory of Botany, Lutheran University of Brazil, Itumbiara, Goiás, Brazil.

Received: 29 April 2015 Accepted: 29 April 2015

Published online: 05 June 2015

\section{References}

Acker SA, Gregory S, Lienkaemper G, McKee WA, Swanson FJ, Miller SD (2003) Composition, complexity, and tree mortality in riparian forests in the central Western Cascades of Oregon. Forest Ecol Manag 173:293-308

Andersson E, Nilsson C, Johansson ME (2000) Effects of river fragmentation on plant dispersal and riparian flora. Regul Rivers 16:83-9

Baker TR, Affum-Baffoe K, Burslem D, Swaine MD (2002) Phenological differences in tree water use and the timing of tropical forest inventories: conclusions from patterns of dry season diameter change. Forest Ecol Manag 171:261-74

Barth JAC, Cronin AA, Dunlop J, Kalin RM (2003) Influence of carbonates on the riverine carbon cycle in an anthropogenically dominated catchment basin: evidence from major elements and stable carbon isotopes in the Lagan River (N. Ireland). Chem Geol 200:203-16

Baxter RM (1977) Environmental effects of dams and impoundments. Annu Rev Ecol Syst 8:255-83
Bendix J, Hupp CR (2000) Hydrological and geomorphological impacts on riparian plant communities. Hydrol Process 14:2977-90

Borchert R (1998) Responses of tropical trees to rainfall seasonality and its long-term changes. Clim Change 39:381-93

Brandao RA, Araujo AFB (2008) Changes in anuran species richness and abundance resulting from hydroelectric dam flooding in Central Brazil. Biokhimiya 40:263-6

Breshears DD, Nyhan JW, Heil CE, Wilcox BP (1998) Effects of woody plants on microclimate in a semiarid woodland: Soil temperature and evaporation in canopy and intercanopy patches. Int J Plant Sci 159:1010-7

Chabot BF, Hicks DJ (1982) The ecology of leaf spans. Annu Rev Ecol Syst 13:229-59

Chazdon RL, Brenes AR, Alvarado BV (2005) Effects of climate and stand age on annual tree dynamics in tropical second-growth rain forests. Ecology 86:1808-15

Chazdon RL, Letcher SG, van Breugel M, Martinez-Ramos M, Bongers F, Finegan B (2007) Rates of change in tree communities of secondary Neotropical forests following major disturbances. Philos T Roy Soc B 362:273-89

Choat B, Ball M, Luly J, Holtum J (2003) Pit membrane porosity and water stressinduced cavitation in four co-existing dry rainforest tree species. Plant Physiol 131:41-8

Choat B, Ball MC, Luly JG, Holtum JAM (2005) Hydraulic architecture of deciduous and evergreen dry rainforest tree species from north-eastern Australia. Trees-Struc Func 19:305-11

Colwell RK (2005) EstimateS: statistical estimation of species richness and shared species form samples. Versão 7:5

Colwell RK, Coddington JA (1994) Estimating the extent of terrestrial biodiversity through extrapolation. Philos T Roy Soc B 345:101-18

Dynesius M, Nilsson C (1994) Fragmentation and flow regulation of river systems in the northern 3rd of the world. Science 266:753-62

Dynesius M, Jansson R, Johansson ME, Nilsson C (2004) Intercontinental similarities in riparian-plant diversity and sensitivity to river regulation. Ecol Appl 14:173-91

Ehleringer JR, Dawson TE (1992) Water-uptake by plants - perspectives from stable isotope composition. Plant, Cell Environ 15:1073-82

Evans A, Strezov V, Evans TJ (2009) Assessment of sustainability indicators for renewable energy technologies. Renew Sust Energ Rev 13:1082-8

Fearnside PM (2002) Greenhouse gas emissions from a hydroelectric reservoir (Brazil's Tucurui Dam) and the energy policy implications. Water Air Soil Poll 133:69-96

Fearnside PM (2005) Brazil's Samuel Dam: Lessons for hydroelectric development policy and the environment in Amazonia. Environ Manage 35:1-19

Gaston KJ (2000) Global patterns in biodiversity. Nature 405:220-227

Guariguata MR, Cronkleton P, Shanley P, Taylor PL (2008) The compatibility of timber and non-timber forest product extraction and management. Forest Ecol Manag 256:1477-81

Gundersen P, Lauren A, Finer L, Ring E, Koivusalo H, Saetersdal M, Weslien JO, Sigurdsson BD, Hogbom L, Laine J, Hansen K (2010) Environmental services provided from riparian forests in the Nordic countries. Ambio 39:555-66

Guo ZW, Li YM, Xiao XM, Zhang L, Gan YL (2007) Hydroelectricity production and forest conservation in watersheds. Ecol Appl 17:1557-62

Gusson AE, Vale VS, Oliveira AP, Lopes SF, Dias Neto OC, Araújo GM, Schiavini I (2011) Interferência do aumento de umidade do solo nas populações de Myracrodruon urundeuva Allemão e Anadenanthera colubrina (Vell.) Brenan em reservatórios artificiais de Usinas Hidrelétricas. Sci Florestalis 39:35-41

Hubble TCT, Docker BB, Rutherfurd ID (2010) The role of riparian trees in maintaining riverbank stability: a review of Australian experience and practice. Ecol Eng 36:292-304

Hughes FMR, Rood SB (2003) Allocation of river flows for restoration of floodplain forest ecosystems: a review of approaches and their applicability in Europe. Environ Manag 32:12-33

Humborg C, Ittekkot V, Cociasu A, VonBodungen B (1997) Effect of Danube River dam on Black Sea biogeochemistry and ecosystem structure. Nature 386:385-8

Hutcheson K (1970) A test for comparing diversities based on Shannon formula. J Theor Biol 29:151-4

Jansson R, Nilsson C, Dynesius M, Andersson E (2000) Effects of river regulation on river-margin vegetation: a comparison of eight boreal rivers. Ecol Appl 10:203-24

Jansson R, Zinko U, Merritt DM, Nilsson C (2005) Hydrochory increases riparian plant species richness: a comparison between a free-flowing and a regulated river. J Ecol 93:1094-103 
Johnson WC (1994) Woodland expansion in the Platte River, Nebraska - patterns and causes. Ecol Monogr 64:45-84

Kaygusuz K (2004) Hydropower and the world's energy future. Energ Source 26:215-24

Kottek M, Grieser J, Beck C, Rudolf B, Rubel F (2006) World Map of the Köppen-Geiger climate classification updated. Meteorol Z 15(3):259-63

Laurance WF, Nascimento HEM, Laurance SG, Andrade A, Ribeiro JELS, Giraldo JP, Lovejoy TE, Condit R, Chave J, Harms KE, D'Angelo S (2006) Rapid decay of tree-community composition in Amazonian forest fragments. Proc Natl Acad Sci U S A 103:19010-4

Lima IBT, Victoria RL, Novo EMLM, Feigl BJ, Ballester MVR, Ometto JP (2002) Methane, carbon dioxide and nitrous oxide emissions from two Amazonian reservoirs during high water table. Verhandlungen I Vereinigung Limno 28:438-42

Lopes SF, Schiavini I (2007) Dinâmica da comunidade arbórea de mata de galeria da Estação Ecológica do Panga, Minas Gerais, Brasil. Acta Bot Bras 21:249-61

Manyari W, Carvalho OA (2007) Environmental considerations in energy planning for the Amazon region: downstream effects of dams. Energ Policy 35:6526-34

Markesteijn L, Iraipi J, Bongers F, Poorter L (2010) Seasonal variation in soil and plant water potentials in a Bolivian tropical moist and dry forest. J Trop Ecol 26:497-508

Moura Júnior EG, Abreu MC, Severi W, Lira GAST (2011) O gradiente rio-barragem do reservatório de Sobradinho afeta a composição florística, riqueza e formas biológicas das macrófitas aquáticas? Rodriguésia 62:731-42

Munoz-Reinoso JC (2001) Vegetation changes and groundwater abstraction in SW Donana, Spain. J Hydrol 242:197-209

Murphy PG, Lugo AE (1986) Ecology of tropical dry forest. Annu Rev Ecol Syst 17:67-88

Naiman RJ, Decamps H (1997) The ecology of interfaces: riparian zones. Annu Rev Ecol Syst 28:621-58

Nepstad DC, Decarvalho CR, Davidson EA, Jipp PH, Lefebvre PA, Negreiros GH, Dasilva ED, Stone TA, Trumbore SE, Vieira S (1994) The role of deep roots in the hydrological and carbon cycles of Amazonian forests and pastures. Nature 372:666-9

Nilsson C, Berggren K (2000) Alterations of riparian ecosystems caused by river regulation. Bioscience 50:783-92

Nilsson C, Svedmark M (2002) Basic principles and ecological consequences of changing water regimes: riparian plant communities. Environ Manag 30:468-80

Nilsson C, Andersson E, Merritt DM, Johansson ME (2002) Differences in riparian flora between riverbanks and river lakeshores explained by dispersal traits. Ecology 83:2878-87

Nilsson C, Jansson R, Zinko U (1997) Long-term responses of river-margin vegetation to water-level regulation. Science 276:798-800

Nilsson C, Reidy CA, Dynesius M, Revenga C (2005) Fragmentation and flow regulation of the world's large river systems. Science 308:405-8

O'Brien EM, Field R, Whittaker RJ (2000) Climatic gradients in woody plant (tree and shrub) diversity: water-energy dynamics, residual variation, and topography. Oikos 89:588-600

Oliveira AT, Fontes MAL (2000) Patterns of floristic differentiation among Atlantic forests in southeastern Brazil and the influence of climate. Biokhimiya 32:793-810

Oliveira-Filho AT, Ratter JA (2002) Vegetation physiognomies and woody flora of the Cerrado Biome. In: Oliveira PS, Marquis RJ (eds) The Cerrados of Brazil. Columbia University Press, New York, pp 91-120

Oliveira-Filho AT, Carvalho WAC, Machado ELM, Higuchi P, Appolinário V, Castro GC, Silva AC, Santos RM, Borges LF, Corrêa BS, Alves JM (2007) Dinâmica da comunidade e populações arbóreas da borda e interior de um remanescente florestal na Serra da Mantiqueira, Minas Gerais, em um intervalo de cinco anos (1999-2004). Rev Bras Bot 30:149-61

Palmer GC, Bennett AF (2006) Riparian zones provide for distinct bird assemblages in forest mosaics of south-east Australia. Biol Conserv 130:447-57

Pascarella JB, Aide TM, Zimmerman JK (2004) Short-term response of secondary forests to hurricane disturbance in Puerto Rico, USA. Forest Ecol Manag 199:379-93

Patz JA, Graczyk TK, Geller N, Vittor AY (2000) Effects of environmental change on emerging parasitic diseases. Int J Parasitol 30:1395-405

Phillips OL, Baker TR, Arroyo L, Hiquchi N, Killeen TJ, Laurance WF, Lewis SL, Lloyd J, Malhi Y, Monteagudo A, Neill DA, Vargas PN, Silva JNM, Terborgh J, Martinez RV, Alexiades M, Almeida S, Brown S, Chave J, Comiskey JA, Czimczik Cl, Di Fiore A, Erwin T, Kuebler C, Laurance SG, Nascimento HEM,
Olivier J, Palacios W, Patino S, Pitman NCA, Quesada CA, Salidas M, Lezama AT, Vinceti B (2004) Pattern and process in Amazon tree turnover, 1976-2001. Philos T Roy Soc B 359:381-407

Reich PB, Wright IJ, Cavender-Bares J, Craine JM, Oleksyn J, Westoby M, Walters MB (2003) The evolution of plant functional variation: Traits, spectra, and strategies. Int J Plant Sci 164:S143-64

Rodrigues RR, Nave AG (2000) Heterogeneidade florística das matas ciliares. In: Rodrigues R. R. and Leitão-Filho H. F. (eds), Matas ciliares: conservação e recuperação, São Paulo, SP., 45-71.

Rodrigues VHP, Lopes SF, Araújo GM, Schiavini I (2010) Composição, estrutura e aspéctos ecológicos da floresta ciliar do rio Araguari no Triângulo Mineiro. Hoehnea 37:87-105

Santos ER, Assunção WL (2006) Distribuição espacial das chuvas na microbacia do Córrego do Amanhece, Araguari - MG. Caminhos da Geografia 6:41-55

Shannon CE (1948) A mathematical theory of communication. AT\&T Tech J 27:379-423

Sheil D, Burslem D, Alder D (1995) The interpretation and misinterpretation of mortality-rate measures. J Ecol 83:331-3

Sheil D, Jennings S, Savill P (2000) Long-term permanent plot observations of vegetation dynamics in Budongo, a Ugandan rain forest. J Trop Ecol 16:765-800

Sidle RC, Ziegler AD, Negishi JN, Nik AR, Siew R, Turkelboom F (2006) Erosion processes in steep terrain - Truths, myths, and uncertainties related to forest management in Southeast Asia. Forest Ecol Manag 224:199-225

Silva AC, Berg EVD, Higuchi P, Oliveira-Filho AT (2007) Comparação florística de florestas inundáveis das regiões Sudeste e Sul do Brasil. Rev Bras Bot 30:257-69

St Louis VL, Kelly CA, Duchemin E, Rudd JWM, Rosenberg DM (2000) Reservoir surfaces as sources of greenhouse gases to the atmosphere: a global estimate. Biokhimiya 50:766-75

Truffer B, Bratrich C, Markard J, Peter A, Wuest A, Wehrli B (2003) Green Hydropower: the contribution of aquatic science research to the promotion of sustainable electricity. Aquat Sci 65:99-110

Vale VS, Schiavini I, Araújo GM, Gusson AE, Lopes SF, Oliveira AP, Prado-Júnior JA, Arantes CS, Dias-Neto OC (2013) Fast changes in seasonal forest communities due to soil moisture increase after damming. International J Trop Biol 61:1901-17

Vartapetian BB, Jackson MB (1997) Plant adaptations to anaerobic stress. Ann Bot 79:3-20

Vorosmarty CJ, Meybeck M, Fekete B, Sharma K, Green P, Syvitski JPM (2003) Anthropogenic sediment retention: major global impact from registered river impoundments. Global Planet Change 39:169-90

White TCR (2007) Flooded forests: death by drowning, not herbivory. J Veg Sci 18:147-8

Wright SJ, Vanschaik CP (1994) Light and the phenology of tropical trees. Am Nat 143:192-9

Xu H, Ye M, Li J (2009) The ecological characteristics of the riparian vegetation affected by river overflowing disturbance in the lower Tarim River. Environ Geol 58:1749-55

\section{Submit your manuscript to a SpringerOpen ${ }^{\odot}$ journal and benefit from:}

- Convenient online submission

$\checkmark$ Rigorous peer review

- Immediate publication on acceptance

- Open access: articles freely available online

- High visibility within the field

- Retaining the copyright to your article

Submit your next manuscript at $>$ springeropen.com 